\title{
REHABILITASI MEDIK PADA PENYAKIT LEGG-CALVÉ-PERTHES
}

\author{
René R. Pradnasurya \\ Engeline Angliadi
}

\author{
Bagian Ilmu Kedokteran Fisik dan Rehabilitasi \\ Fakultas Kedokteran Universitas Sam Ratulangi Manado \\ Email: renepradnasurya@gmail.com
}

\begin{abstract}
In Legg-Calvé-Perthes disease there is an avascular necrosis condition of the femoral head with a clinical onset between the ages of 2-12 years old. The etiology of this disease remains unknown. Its variable clinical symptoms and disease progression depend on the severity of the disease. The principle of therapy is hip containment. Rehabilitation programs play an important role to revert or to maximize the function and activities of daily living. We reported a case of a 9-year-old girl with complains of limpness, asymmetric lower extremities, weakness of the right lower extremity, pain around the right knee, with a history of trauma on the right hip 5 months ago. Physical examination revealed weakness of the right hip flexor and knee extensor with limitation of the right hip's range of motions. The X-ray taken showed an avascular necrosis appearance at the right femoral head. Conclusion: This case was diagnosed as Legg-Calvé-Perthes disease based on anamnesis, physical examination, and the X-ray result. The rehabilitation management for this case was heat modality with infra red to prepare the muscle condition for exercises, muscle strengthening and range of motion exercises to prevent contracture, as well as medical education with psychological support. Scottish Rite orthosis was planned to position the hip in abduction while limiting the hip adduction.
\end{abstract}

Keywords: Legg-Calvé-Perthes, avascular necrosis, comprehensive rehabilitation.

\begin{abstract}
Abstrak: Pada penyakit Legg-Calvé-Perthes terjadi kondisi nekrosis avaskular kaput femur dengan usia awitan paling sering antara usia 2-12 tahun. Etiologi penyakit ini masih belum diketahui, dengan perjalanan dan gambaran klinis yang bervariasi tergantung dari tingkat keparahan penyakit. Prinsip terapi penyakit ini ialah hip containment. Program rehabilitasi diberikan secara komprehensif baik dari fisioterapi, terapi okupasi, ortotik-prostetik, psikologi, serta sosial medik yang sangat berperan dalam mengembalikan atau memaksimalkan fungsi dan aktivitas kehidupan sehari-hari. Kami melaporkan kasus seorang anak perempuan usia 9 tahun dengan keluhan berjalan pincang, asimetris antara tungkai kanan dan kiri, kelemahan tungkai kanan, nyeri sekitar lutut kanan, dengan riwayat trauma panggul kanan 5 bulan lalu. Pada pemeriksaan fisik ditemukan kelemahan otot fleksor panggul dan ekstensor lutut kanan serta keterbatasan lingkup gerak sendi panggul kanan. Pada pemeriksaan radiologik terlihat gambaran nekrosis avaskular kaput femur kanan. Simpulan: Pada kasus ini, diagnosis penyakit Legg-Calvé-Perthes ditegakkan berdasarkan anamnesis, pemeriksaan fisik, dan pemeriksaan radiologik. Penanganan rehabilitasi yang diberikan ialah modalitas panas berupa sinar infra red untuk mempersiapkan kondisi otot sebelum latihan, latihan penguatan otot dan lingkup gerak sendi untuk mencegah kontraktur, serta edukasi baik dari sisi medik maupun psikologik. Juga direncanakan pemberian Scottish Rite orthosis untuk membuat posisi panggul menjadi abduksi dengan membatasi gerakan adduksi.
\end{abstract}

Kata kunci: Legg-Calvé-Perthes, nekrosis avaskular, rehabilitasi komprehensif. 